Part V

The Quest for Balance Regarding Criminal Justice Actors and in Their Mutual Relations 


\title{
A Comparison of the Evolution and Pace of Police and Judicial Cooperation in Criminal Matters: A Race Between Europol and Eurojust?
}

\author{
SABINE GLESS AND THOMAS WAHL
}

\section{About Roles and Functions}

When thinking about how to address the 'Comparison of the evolution and pace of police cooperation and judicial cooperation' topic, we immediately thought about a purported Europol vs Eurojust 'race' - a kind of disequilibrium or competitive relationship that could be observed in the last 10 years. We realised thatat least from the perspective of a university 'ivory tower'-it would not be easy to discover the rules of this comparison between police cooperation and judicial cooperation, since this cooperation features a multitude of legal frameworks, working languages, actors and stakeholders. ${ }^{1}$

Starting from the drawing board of EU policy-makers, the two EU agencies in charge of cross-border cooperation in criminal matters developed more or less according to the plan set by national decision-makers, in their respective fields:

Europol has been responsible for police cooperation and data exchange from an early stage, but it has, up to now, had no formal executive power or command over national law enforcement authorities and thus bears very limited responsibility for 'operations on the ground'; the cyberspace, however, may be a different matter. ${ }^{2}$

${ }^{1}$ Cf M Coninsx, 'Eurojust' in V Mitsilegas, M Bergström and T Konstadinides (eds), Research Handbook on European Criminal Law (Edward Elgar, 2016) 454: 'yet the European Union is composed of interactions among 30 different legal systems and 24 working languages. Such differences between national legal systems must be taken into account when establishing a novel European actor and its set of competences'.

2 Cf Council Decision 2009/371/JHA [2009] OJ L121/37, Recital 7; see also S Gless, 'Europol' in V Mitsilegas, M Bergström and T Konstadinides (eds), Research Handbook on European Criminal Law (Edward Elgar, 2016) 460. 
Europol is considered the hub for information exchange in the Union-a role that is in the literature also described as Europol being the Union's main 'information broker' in the area of criminal law enforcement. ${ }^{3}$

By comparison, Eurojust, which is responsible for the coordination of and cooperation between the judicial authorities of the 28 EU Member States, appears to be inherently more reserved and seems to stay a cautious step or two behind Europol due to its role as a judicial authority. Although Eurojust's operational capacities were stepped up in $2008,{ }^{4}$ Eurojust is mainly a coordinator and advisor that pays close attention to traditional legal frameworks. Its role can be briefly described as a 'supranational coordinating and clearing house', which is able to quickly solve legal problems or render mutual legal assistance more effective when national prosecutions deal with cross-border crime. ${ }^{5}$

On the basis of these initial considerations, it is assumed that the roles of these two European Union bodies essentially are the same as those allocated at national level: the police involved in operational actions and the judiciary balancing the different interests at stake. It therefore appears that the question is not so much about the challenge as to who is first or who is a step ahead in a race between the police and the judiciary but rather whether the two bodies have found their place within the scenario of multi-level law enforcement. ${ }^{6}$

In the following section (II), we verify this assumption by looking at the development of these two European Union agencies and their mission in the area of freedom, security and justice. This is exemplified by the agencies' role in the fight against terrorism and cybercrime. ${ }^{7}$ We further scrutinise whether our analysis of the status quo will be valid in view of the reform of the legal frameworks governing the role and function of the two bodies. The adaptations under the European Union`s Lisbon Treaty have been made for Europol by Regulation (EU) 2016/794 of 11 May 2016, ${ }^{8}$ and the question arises as to what will come out of it in the future. Subsequently, in section III, we examine which (common) challenges the two institutions must meet henceforth, focusing on two issues: (A) are Europol and Eurojust able to find a European response to new cross-border crime phenomena; and $(\mathrm{B})$ is accountability ensured for them and their agents?

\footnotetext{
3 Cf T Wahl, 'The European Union as an Actor in the Fight Against Terrorism' in M Wade and A Maljevic (eds), A war on terror? (Springer 2010) 107, 144.

4 Council Decision 2009/426/JHA [2009] OJ L138/14. For the reform see also Michèle Coninsx (n 1 above) 442 et seq.

5 T Wahl (n 3 above) 147.

6 The term 'law enforcement' is used here in a wider sense not only referring to police and other competent law enforcement authorities which dissuade or discover criminal activity, but also includes the investigation and prosecution of criminal behaviour by the judiciary, ie the prosecutorial services and the criminal courts. For the use of the term in this sense of (1974) 124 New Law Journal Part 1, p 358.

7 Other areas of possible comparison could have been the trafficking in human beings, smuggling, large-scale fraud, etc.

${ }^{8}$ Regulation (EU) 2016/794 of the European Parliament and of the Council on the European Union Agency for Law Enforcement Cooperation (Europol) and replacing and repealing Council Decisions 2009/371/JHA, 2009/934/JHA, 2009/935/JHA, 2009/936/JHA and 2009/968/JHA [2016] OJ L135/53.
} 


\section{Mission Accomplished-Where does One Go Now?}

The European Union's law-maker has set clear goals for both agencies giving them a mission for criminal justice cooperation, on the one hand, and police cooperation, on the other.

According to Article 85 TFEU, Eurojust's mission is to support and strengthen coordination and cooperation between the national authorities of the $28 \mathrm{Member}$ States that conduct investigations into and prosecute serious cross-border crime. By equipping Eurojust with coordination and cooperation tools, promoting a fluent exchange of information, giving it the mandate to assist with the application of the EU's legal instruments based on the principle of mutual recognition of judicial decisions, and endorsing best practices across the EU, Eurojust contributes to close cross-border cooperation among the competent judicial authorities.

Europol's mission, on the other hand, is - according to Article 88 TFEU-to support and strengthen action by the Member States' police authorities and other law enforcement services. Within this mandate it will prevent and combat serious crime affecting two or more Member States, including terrorism and crimes which affect a common interest covered by a Union policy. By improving and facilitating information sharing by the competent national law enforcement authorities with Europol, equipping Europol with data systems and capacities to produce strategic intelligence, establishing specialist knowledge (such as in the area of cybercrime) and extending Europol's abilities to cooperate and build up partnerships with other EU institutions, international organisations and third states, as well as the private sector, Europol could fulfill its role as a support unit to national law enforcement activity.

Overall, both institutions have accomplished the goals given to them by primary EU law in recent decades. Is that enough? The answer depends on one's ambition for the future of EU cooperation.

\section{A. Europol}

Europol commenced its activities in 1999 after Member States had agreed on the establishment of a European Police office and eventually adopted the Europol Convention. ${ }^{9}$ Its predecessor, the European Drugs Unit (EDU) had already become operational in the early 1990s. ${ }^{10}$

\footnotetext{
9 For further information see S Puntscher Rickmann, 'Security, Freedom and Accountability: Europol and Frontex' in E Guild and F Geyer (eds), Security versus Justice? Police and Judicial Cooperation in the European Union (Ashgate 2009) 19-20.

${ }^{10}$ For further information see: F R Monaco, 'Europol: The Culmination of the European Union's International Police Cooperation Efforts' (1995) 19 Fordham International Law Journal 247, 282.
} 
From the very start, Europol's mandate was directed to 'action', but predominantly in the digital world and in the processing of data.

As is well known, Europol was designed from the start with a main focus on data exchange between the national authorities of EU Member States and as the nucleus of a European intelligence unit. ${ }^{11}$ The data mandate was subsequently extended to more areas of crime (including, for instance, terrorism) ${ }^{12}$ but the EU Member States never ventured into making Europol a European 'FBI' with real operational competences. Article 88 paragraph 3 TFEU still sets the limit:

Any operational action by Europol must be carried out in liaison and in agreement with the authorities of the Member State or States whose territory is concerned. The application of coercive measures shall be the exclusive responsibility of the competent national authorities.

In 2009, Europol was transformed into an EU agency. This transformation strengthened the European influence on Europol as it made it subject to general rules and procedures applicable to EU agencies. ${ }^{13}$ These general rules and procedures not only include budgeting and auditing, but also affect the revision of the legal basis and - to a limited extent—-the judicial oversight of Europol by the Court of Justice of the European Union (CJEU). ${ }^{14}$

Europol's powers lie basically in producing intelligence, ${ }^{15}$ but it also offers direct assistance to national units. Europol's activities with regard to preventing and combating alleged terrorist threats are a good example in this context. Two months after the terrorist attacks of $9 / 11$ in the US the Counter-Terrorist Task Force (CTTF) became operational. In 2007, the CTTF was transferred to the First Response Network. Europol was mandated to (1) collect in a timely manner all relevant information and intelligence concerning the current terrorist threat in the EU; (2) analyse the collected information and undertake the necessary operational and strategic analysis; and (3) draft a threat assessment document based on information received. ${ }^{16}$ In addition, Europol developed several products and services that assist law enforcement authorities in the Member States in conducting ongoing investigations. ${ }^{17}$ Europol has adjusted its capabilities continuously.

11 Monaco (n 10 above), 248-49, 274-77.

12 C Ladenburger, 'Police and criminal law in the Treaty of Lisbon: a new dimension for the Community method' (2008) 4 European Criminal Law Review 20, 23; Thomas Wahl (n 3 above) 144-45.

13 See, for instance, M Tebaldi/M Calaresu, 'Level of Europeanization and Policy Outcomes: The Common Security Policy and the Case of Europol' (June 2013) SAGE Open, 7.

14 S Gless (n 2 above) 464 et seq.

15 For further information on the importance of data exchange as part of EU policy: M Fletcher, R Lööf and B Gilmore, EU Criminal Law and Justice (Edward Elgar Publishing 2008) 92-97; A Nunzi, 'Exchange of information and intelligence among law enforcement authorities. A European Union perspective' (2007) 78 Revue internationale de droit pénal 143, 147-48.

16 T Wahl (n 3 above) 145; see furthermore S Rozée, C Kaunert and S Léonard, 'Is Europol a Comprehensive Policing Actor?' (2013) 14 Perspectives on European Politics and Society 374.

17 See, for instance, Europol Review, General Report on Europol Activities, 2009, p 17. 
In January 2016, the European Counter Terrorism Centre (ECTC) was launched at Europol and reacts to the new Jihadist terrorism which threatens the EU (in particular marked by the attacks on Charlie Hebdo in January 2015). The main function of the ECTC is to be a hub to exchange information, conduct analysis and coordinate operational support. The ECTC is able to provide quick and effective support on a 24/7 basis to counter-terrorism and criminal investigations when the terrorist event has a transnational or international scope. The support includes the analyses of an enormous amount of data generated by the criminal investigations, establishment of mobile offices or provision of Arab language experts who are able to monitor websites and social media in Arabic or track networks that support the financing of terrorist activities. ${ }^{18}$

Beyond the fight against specific physical cross-border crime threats, Europol is largely involved in preventing and combating cybercrime. Europol has been using its cybercrime mandate and has been hosting the European Cybercrime Centre (EC3) since 2013. The EC3 ${ }^{19}$ is meant to coordinate cross-border law enforcement activities against cybercrime, provide technological expertise to the competent national authorities and assist national authorities in their efforts to dismantle and disrupt cybercrime networks. The EC3 has a promising future and has already expanded its staff and activities. Among other projects, it hosts a Joint Cybercrime Action Taskforce (J-CAT), which is composed of cyber liaison officers from EU Member States and non-EU partners, as well as officers from EC3. The taskforce operates in a rather flexible legal framework, following the objective 'to pro-actively drive intelligence-led, coordinated action against key cybercrime threats and top targets. ${ }^{20}$

The new legal framework confirms Europol's shift in its action to focus police work on cyberspace. Regulation (EU) 2016/794 now provides a legal setting for this approach by pointing out, in the description of Europol's task, that the (already existing) European Cybercrime Centre should be further developed and that Europol is to support Member States' actions in preventing and combating forms of crime which are facilitated, promoted or committed using the Internet. ${ }^{21}$

In addition, the new legal framework seems to change the role of Europol. In this regard, two issues are particularly striking for us, which are somewhat hidden in Regulation (EU) 2016/794. Firstly, the new Regulation indeed still contains a provision according to which Europol can request Member States to initiate criminal investigations. However, a few changes have been inserted. For instance, the new provision refrains from using the words that the Member States

18 For more information about the ECTC see https://www.europol.europa.eu/crime-areas-andtrends/crime-areas/terrorism, accessed 3 August 2017; see also Cornelia Riehle, (2016) eucrim 69-70.

19 Europol, 'European cybercrime centre-EC3': https://www.europol.europa.eu/about-europol/ european-cybercrime-centre-ec3, accessed 3 August 2017.

20 See Europol, 'Joint cybercrime action taskforce (J-CAT)': https://www.europol.europa.eu/ec3/ joint-cybercrime-action-taskforce-j-cat, accessed 3 August 2017.

21 Regulation (EU) 2016/794 (n 8 above), Art 4 para $1(1)$ and (m). 
shall give such requests 'due consideration'22 and introduces a time-limit for national authorities to justify their decision not to follow Europol's requests. ${ }^{23}$ Herewith, Europol's request should become more 'powerful' although the request remains non-binding in nature since it is (still) up to the national authorities to comply with the request or not. As a consequence, however, Europol's abilities to instruct or direct national police authorities to launch criminal investigations are reinforced by the new provision. ${ }^{24}$

Even more prominent is the second issue: Regulation (EU) 2016/794 stresses that Europol should 'have the fullest and most up-to-date information possible ... in order to develop an understanding of criminal phenomena and trends to gather information about criminal networks, and to detect links between different criminal offences.' ${ }^{25}$ Europol further explicitly receives a green light 'to choose the most efficient IT structure', in order to 'be able to swiftly detect links between investigations and common modi operandi across different criminal groups, to check cross-matches of data and to have a clear overview of trends. ${ }^{26}$ This 'vision' is implemented by Article 18 which foresees, inter alia, that Europol may process personal data for the purpose of 'operational analyses'. Although Article 18 paragraph 3 of Regulation (EU) 2016/794 includes some guarantees for data protection, in the case of these 'operational analyses', the legal text nowhere mentions 'how' these analyses are carried out. In short, the new legal framework endorses Europol's capacity in carrying out data-mining operations. Data mining is defined as the technique of exploring sets of data in order to identify interesting structures in the data, including patterns, statistical or predictive models of the data and relationships among parts of the data. ${ }^{27}$ This possibility presents certain risks with regard to respect for data protection standards and illustrates once more Europol's move towards having a more active role, almost comparable to the role of national police services. If Europol goes down this road, it must also meet the requirements for police authorities with regard to accountability set for national police.

22 Cf Art 7 para 1 Council Decision 2009/371/JHA vs. Art 6 para 1 Regulation (EU) 2016/794.

23 Regulation (EU) 2016/794 (n 8 above), Art 6 paras 1 and 2 read as follows:

'(1) In specific cases where Europol considers that a criminal investigation should be initiated into a crime falling within the scope of its objectives, it shall request the competent authorities of the Member States concerned via the national units to initiate, conduct or coordinate such a criminal investigation.

(2) The national units shall inform Europol without delay of the decision of the competent authorities of the Member States concerning any request made pursuant to paragraph 1.'

${ }^{24}$ See Regulation (EU) 2016/794 (n 8 above), Art 6: 'In specific cases where Europol considers that a criminal investigation should be initiated into a crime falling within the scope of its objectives, it shall request the competent authorities of the Member States concerned via the national units to initiate, conduct or coordinate such a criminal investigation.'

25 Regulation (EU) 2016/794 (n 8 above), Recital 23.

26 Regulation (EU) 2016/794 (n 8 above), Recital 24.

27 R Sicurella and V Scalia, 'Data Mining and Profiling in the Area of Freedom, Security and Justice' (2013) 4 New Journal of European Criminal Law 409, 420 with further references. 


\section{B. Eurojust}

By comparison, Eurojust's work appears to be rather low-key in nature. A provisional unit (called Pro-Eurojust) located in Brussels started to operate some years after Europol, in March 2001, with the mission to enhance judicial cooperation in criminal matters. The terrorist attacks of 11 September 2001 accelerated the development of various forms of judicial cooperation, including the formal establishment of Eurojust in 2002 by a Council Decision, ${ }^{28}$ with a seat in The Hague.

Today, after the revision of Eurojust's legal framework in 2008, a strengthened College, composed of one National Member for each Member State, is responsible for Eurojust's organisation and operation. ${ }^{29}$ The main task is to solve conflicts of jurisdictions or difficulties in mutual legal assistance in criminal matters, such as extradition/surrender or the collection of evidence abroad. All College Members have a minimum set of powers to operate from their desk in their respective home countries; the powers, however, are set by national legislation.

Eurojust has not been designed for operational action. Its priority rather lies in increasing levels of judicial networking. An important tool in this regard is the Eurojust National Coordination System (ENCS). Its goal is to guarantee in each Member State the effective and swift flow of information between the judicial authorities at the national level, from the national member to Eurojust and from the national contact points to the European Judicial Network in criminal matters (EJN). ${ }^{30}$ A Eurojust National Correspondent in each Member State is responsible for the functioning of the ENCS and the correspondent serves as 'the lighthouse' for the other ENCS members, and for the Eurojust National Member. ${ }^{31}$ By means of the ENCS, the tasks of Eurojust in the Member States should be facilitated, ensuring, inter alia, that Eurojust's case management system is fed with enough and reliable information and defining Eurojust's competence in relation to the EJN. ${ }^{32}$

As mentioned above, the establishment of Eurojust is closely linked to the terrorist attacks of 2001. As a result, Eurojust is also considered a key player in the EU's fight against terrorism, and combating terrorism is one of its priorities. ${ }^{33}$

${ }^{28}$ Council Decision 2002/187/JHA of 28 February 2002 setting up Eurojust with a view to reinforcing the fight against serious crime [2002] OJ L63/1.

${ }_{29}$ Council Decision 2009/426/JHA of 16 December 2008 on the strengthening of Eurojust and amending Decision 2002/187/JHA setting up Eurojust with a view to reinforcing the fight against serious crime. This Decision was adopted by the Council in December 2008 and took effect on the day of its publication in the Official Journal of the European Union [2009] OJ L138/1 (04.06.2009).

30 Á Gutiérrez Zarza, Exchange of Information and Data Protection in Cross-border Criminal Proceedings in Europe (Springer 2015) 79.

31 'Eurojust paper on the ENCS structure and profile of the national correspondent for Eurojust' (Eurojust, 11 July 2011): http://www.eurojust.europa.eu/Practitioners/objectives-tools/Documents/Eurojust $\% 20$ Note $\% 20$ on $\% 20$ the $\% 20$ Eurojust $\% 20$ National $\% 20$ Coordination $\% 20$ System $\%$ 20\%28ENCS\%29/ENCS-and-National-Correspondent-for-Eurojust.pdf, accessed 3 August 2017.

32 See also Art 12 para 5 of the 2008 Eurojust Council Decision (n 29 above).

33 T Wahl (n 3 above) 147; Eurojust News (October 2009) Issue No 1 on the fight against terrorism. 
In the wake of the terrorist attacks in Madrid in March 2004, the College of Eurojust set up a Counter-Terrorism (CT) Team within Eurojust and also created a scoreboard by means of which Eurojust keeps track of the progress achieved in major counter-terrorism initiatives. ${ }^{34}$ The major purpose of these steps was to improve and facilitate networking, since a decision was taken 'to progress from purely reactive coordination efforts to more proactive ... contributions in the fight against terrorism. ${ }^{35}$ Furthermore, Eurojust strives to gain expertise in all aspects of the phenomenon of terrorism. Since 2005, Member States have been obliged to designate National Correspondents for Terrorism. These correspondents must provide Eurojust with certain items of information, including data which identify the person, group or entity that is the object of a criminal investigation or prosecution; the offence concerned and its specific circumstances; information about final convictions for terrorist offences and the specific circumstances surrounding those offences; links with other relevant cases; and requests for judicial assistance, including letters rogatory, addressed to or by another Member State and the response. ${ }^{36}$ The information received is processed in Eurojust's case management system and analysed, if necessary, by legal analysts. ${ }^{37}$

Recently, Eurojust has also been more and more involved in the fight against cybercrime. It set up a Task Force on Cybercrime and is supporting the European Judicial Cybercrime Network. The cybercrime network brings together practitioners to share their experience and expertise regarding the challenges that are faced during investigations and prosecutions of cybercrime or cyber-enabled crimes, such as electronic evidence, the differentiated treatment of specific categories of data in criminal proceedings, encryption or jurisdiction. ${ }^{38}$ Recently, Eurojust also took up efforts to strengthen cooperation between the judicial and law enforcement authorities and takes part in some of Europol's anti-cybercrime activities. ${ }^{39}$

One of Eurojust's most powerful tools remains rather informal and low profile: coordination meetings. In such meetings, Eurojust brings together judicial authorities from different Member States to exchange information on a specific case, to overcome possible obstacles to cooperation, and to ensure the speedy execution of requests for judicial cooperation. Such meetings allow for the exchange of information as well as for legal discussions. Both may lead to criminal investigations in the Member States.

34 O Bures, EU Counterterrorism Policy-A Paper Tiger? (Routledge 2011) 117.

35 Cited by Oldrich Bures (n 34 above) referring to an Interview with Michèle Coninsx, at that time Chair of the Counter-Terrorism Team of Eurojust, in September 2009.

36 Council Decision 2005/671/JHA of 20 September 2005 on the exchange of information and cooperation concerning terrorist offences [2005] OJ L253/22, Art 2 paras 2, 3 and 5.

37 Eurojust News (October 2009) Issue No 1, p 3.

38 Cf Eurojust press release of 25 November 2016, 'Kick-off meeting for the European Judicial Cybercrime Network': http://www.eurojust.europa.eu/press/PressReleases/Pages/2016/2016-11-25. aspx, accessed 3 August 2017. For the underlying Council Conclusions see Thomas Wahl, (2016) eucrim 75.

39 Eg with a representative at the EC3 (cf Eurojust Annual Report 2015: http://www.eurojust. europa.eu/doclibrary/corporate/eurojust\%20Annual\%20Reports/Annual\%20Report\%202015/ Annual-Report-2015-EN.pdf, accessed 3 August 2017, p 33). 
In addition, Eurojust was granted several powers to exert influence on national investigations and prosecutions, such as the right to ask the competent authorities of the Member States concerned to undertake an investigation or prosecution of specific criminal acts, to request Member States to coordinate among themselves, to ask for specific investigative measures to be taken or to take any other measure justified for the investigation or prosecution of a case. ${ }^{40}$ In addition, the national members of Eurojust are — subject to national legislation — entitled to exercise certain powers in their capacity as a competent national authority. Most national members are entitled, for instance, in agreement with a national competent authority to issue complete requests for judicial cooperation, to execute in their Member State requests for judicial cooperation or to order in their Member State investigative measures considered necessary at a Eurojust coordination meeting. ${ }^{41}$

As with Europol, Eurojust's legal framework is under review. Likewise, Eurojust is to be 'Lisbonised', meaning that its structures and governance are to be aligned to the setting of the Lisbon Treaty (more precisely: the Treaty on the Functioning of the EU (TFEU)) as well as to the EU's approach of de-centralised agencies. ${ }^{42}$ Similarly to Europol, the (current) legal basis of the Council Decision is to be replaced by a Regulation. In 2013, the Commission tabled a proposal, ${ }^{43}$ on which the JHA Council reached a general approach at its meeting on 12-13 March $2015 .{ }^{44}$ One of the objectives of the Eurojust reform is to strengthen the operational work in the fight against cross-border crime, as well as to increase operational effectiveness. It is explicitly mentioned that Eurojust should act 'on its own initiative', by which Eurojust is imputed a more 'proactive role'. ${ }^{45}$ However, we must wait for the outcome of the negotiations of the legal text to know what that really means.

\section{Europol vs Eurojust?}

Coming back to our preliminary question of whether there is a 'race' to discover between police and judiciary at the European level, or whether both agenciesEuropol and Eurojust - have found their own place in the European Union's setting of combating cross-border crime: the reader may first observe that both have undergone parallel developments in priority policy areas, such as terrorism

40 Council Decision 2009/426/JHA [2009] OJ L138/14, Art 6 para 1(a). Eurojust here acts through its national member(s) concerned. In a reduced manner, similar rights were conferred on the College of Eurojust, see Art 7 para 1(a) of said Council Decision.

41 Cf Council Decision 2009/426/JHA [2009] OJ L138/14, Art 9b. See also Coninsx (n 1 above) 445.

42 See also Coninsx (n 1 above) 452-53.

43 Proposal for a Regulation on the European Union Agency for Criminal Justice Cooperation (Eurojust), COM(2013) 534 final. For an overview of the proposal and a first analysis see A Weyembergh, 'An Overall Analysis of the Proposal for a Regulation on Eurojust' (2013) eucrim 127.

${ }^{44}$ Further negotiations were put on hold in 2015 because advancement of the Regulation on the European Public Prosecutor's Office was awaited. The following refers to the draft regulation on Eurojust in the version of the last and publicly available amendments by the Council: Council doc 6643/15 of 27 February 2015.

45 Coninsx (n 1 above) 453. See also Art 2 para 3 of the Draft Regulation, Council doc 6643/15. 
and cybercrime. Looking at the subject-matter may lead to the conclusion that Eurojust is lagging behind Europol. Whereas Europol began to increase its capacity to tackle terrorism shortly after 2001, it took the terrorist attacks of Madrid in 2004 for Eurojust to reinforce its structures to tackle the phenomenon of terrorism. Likewise, whereas Europol had already started to intensify expertise and knowledge about the crime phenomenon of cybercrime in 2013, Eurojust seems to have created similar structures three years later in $2016 .{ }^{46}$ But on the national level, too, police force and judicial authorities keep up with the changing world of crime at a different pace.

However, the seemingly nearly identical powers of both agencies to request national authorities to initiate criminal investigations could indicate that there is competition between them. Is Europol not by nature regularly quicker to process relevant investigative data and forward them to national counterparts accompanied with the request to go ahead with criminal investigations in the case which may flow in criminal prosecutions? And yet, from a continental European point of view, should it not be the rule that the 'judiciary' - ie Eurojust - takes the lead in providing the impetus for opening criminal prosecutions?

Even if one takes the perspective of the inquisitorial model for criminal justice systems, with strong public prosecution services and 'juges d'instruction', who are in charge of criminal prosecution in many countries of the European continent, we do not believe that we can speak today about a 'race' or 'competition'. It is more appropriate to emphasise the functions of the two EU bodies in the area of freedom, security and justice. Focusing again on the EU's architecture, Europol and Eurojust have, to date, each fulfilled their assigned function. It has been correctly observed that both institutions target, in the first place, different audiences: national police authorities on the one hand; prosecutors and other judicial authorities on the other. ${ }^{47}$ Therefore, 'their activities are driven by different logics and concerns. ${ }^{48}$ Europol's work has always been directed to 'action'; it is marked by efficiency, pro-activeness and pragmatism. ${ }^{49}$ By contrast, Eurojust has-in a quiet and discreet way-increasingly fulfilled its key role as 'facilitator' in enhancing judicial coordination and cooperation within the EU; this is also true for the aforementioned crimes of terrorism and cybercrime. Eurojust does its work more behind the scenes and is less visible. It is to be understood from this that its work is focused on formalism and legal compliance, characteristics that correspond to judicial mindsets. ${ }^{50}$

${ }^{46}$ However, it should not be ignored that Eurojust has invested efforts in the fight against child pornography on the Internet in the past.

47 A Weyembergh, I Armada and C Brière, 'The inter-agency cooperation and future architecture of the EU criminal justice and law enforcement area' (2014) Study for the LIBE Committee, 2014: http:// www.europarl.europa.eu/RegData/etudes/STUD/2014/510000/IPOL_STU\%282014\%29510000_ EN.pdf, accessed 3 August 2017, section 2.1.1.1(b).

48 Ibid.

49 Ibid.

50 Ibid. 
This conclusion remains the same if we look at the agencies' powers to request the initiation of criminal proceedings in the EU Member States. Attention must be drawn to the fact that Europol and Eurojust operate in a multi-level criminal law enforcement environment, which respects the characteristics of the national criminal justice systems. Criminal investigations may be dealt with in one country by judicial authorities and in another by a police authority. The existence of two rights to ask for criminal investigations/prosecutions to be initiated is acceptable as long as it remains up to the national legal order how to further proceed with the information received from the supranational level.

Eventually, an important issue to consider when the two institutions are assessed is that although identical terms, such as 'operation' or 'pro-activeness' are used, their meaning may differ in different contexts. ${ }^{51}$ Thus, the emphasis on increasing the operational capabilities of Eurojust in the new draft Regulation does not mean that Eurojust is given new powers to carry out operations, ${ }^{52}$ but rather refers to a change of internal structures so that the national members of Eurojust can better concentrate on the casework, instead of spending time with additional administrative and managerial issues. ${ }^{53}$ Similarly, the notion that Eurojust should have a more pro-active role refers to the coordination of cases ${ }^{54}$ rather than that it should carry out real operational analysis, which is work that continues to be reserved for Europol.

If the assessment that there is 'no race' taking place between the two agencies, but rather a common effort in accordance with their respective raisons d'être still holds true, the question remains as to whether this assessment is still valid if one looks less at the historical side of their activities, but rather on the future competences assigned to Europol. In fact, today we might be facing a decisive break with the past. If Europol makes full use of its new competences and focuses on operational analyses, including data mining, its role could develop into a pace-setter as a 'main detector of criminal activities' within the EU. ${ }^{55}$ As a consequence, it would indeed be the supranational police force that takes the lead in producing evidence and it would be the judicial service (Eurojust) that would be behind, functioning as a sole 'executor' of the police material. ${ }^{56}$ If we add Europol's competences to request national authorities to initiate criminal investigations, there is even a growing risk that Europol could bypass its judicial counterpart at the supranational level and

51 Weyembergh, Armada and Brière (n 47 above), section 2.1.3.4.

52 See also the Draft Regulation on the powers of the national members, Council doc 6643/15, Art 8 which, in substance, is going to take over the current legislation.

53 Coninsx (n 1 above) 453.

${ }^{54}$ Cf Draft Regulation on Eurojust, Council doc 6643/15, Recital 10.

55 De Capitani remarks in this regard that Europol by trying to become the main EU's intelligence information hub is brought closer to the model of an EU National Security Agency than to a European FBI as it was in its first place (https://free-group.eu/2015/12/06/the-new-europol-no-more-europeanfbi-not-yet-european-nsa/, accessed 3 August 2017). The trend can already be observed in the field of Europol's role in strategic analysis.

56 For keeping Eurojust's role as a mediator/facilitator in the current draft proposal of a Regulation on Eurojust, see Weyembergh (n 43 above), (2013) eucrim 127, 130. 
act 'on its own initiative'. It is hoped, however, that both agencies will constantly work together and that Europol will not rush ahead without involving Eurojust properly. ${ }^{57}$

\section{Challenges for the Future-Law in Action}

It is not enough just to put Europol and Eurojust side by side and to compare them. If we want to fulfill our task, we must also take into account which common challenges both institutions will face in the future and how these challenges are to be met. In this context, we will focus on two issues:

- coming up with a European value-based response to cross-border crime;

— securing adequate accountability for the agencies themselves and their agents.

\section{A. Delivering a European Value-based Response}

A European response to cross-border crime must transcend national perspectives by combining ideas and pooling resources from the national criminal justice systems and giving priority to European values. Transcending national perspectives means striving to develop an overall picture but it does not mean merely piling up more information; it can also mean identifying weaknesses and speaking up. As a chain is only as strong as its weakest link, information exchange and cooperation only works when everyone assists with it. Therefore, Europol and Eurojust must not only be provided with new databases, but the national police forces and other authorities must agree on and implement an adequate model of informationsharing. The relevant authorities must identify weaknesses and speak up about them, not only but also with regard to efficiency in terms of cooperation. In other words: in order to give a European response, the European agencies must strive not only for efficiency, but also for values. That is not only necessary with regard to the Member States' level, but also with regard to the European or even global level.

Consequently, when implementing certain instruments, both Europol and Eurojust must themselves balance their interests in terms of the efficient prevention and combating of crimes, with the protection of human rights, including the citizens' right to privacy and protection of personal data as a European value nurtured in the history of this continent. ${ }^{58}$ Again, Europol might be more exposed than Eurojust, and not solely in the domain of terrorism, but also in its cyberspace

${ }^{57}$ Instructive in this regard, Weyembergh, Armada and Brière (n 47 above), section 2.1.3.1.

58 See: F Bignami, 'European Versus American Liberty: A Comparative Analysis of Antiterrorism Data Mining' (2007) 48 Boston College Law Review 676; E De Busser, 'Examples and Assumptions: Transatlantic Data Protection in Criminal Matters' (2012) 15 Journal of Internet Law 3, 8-9. 
activities. For instance 'cyber patrols' and subsequent profiling will raise privacy and human rights concerns. ${ }^{59}$

The meaning of a 'European' response in practice becomes particularly relevant if Europol and Eurojust interact with authorities outside the European Union. Reference in this regard must be made to the 'safe harbour'-decision of the CJEU. ${ }^{60}$ On the one hand, it was right that the European Union itself gave an answer to transnational data transfer agreements. Despite criticism of the deal reached between the EU and the US, such a mechanism for transferring data across the Atlantic would not have, and could not have been negotiated by one European country on its own. On the other hand, the decision of the CJEU sets clear guidelines (also by referring to the landmark 'Digital Rights Ireland' decision ${ }^{61}$ ) on what are the essential European data protection standards and the European values of proportionality and accountability. ${ }^{62}$ The CJEU further clarified these principles when it recently stated that the planned agreement on the transfer of Passenger Name Record Data to Canada partly does not meet requirements of fundamental rights and data protection in the European Union. ${ }^{63}$ It is therefore up to the European public authorities, including Europol and Eurojust, to raise the 'European' voice when it comes to data transfers from and to third countries, in particular the US. The agreements of Europol and Eurojust on the exchange of data with third parties might be put under overall critical scrutiny and review in the light of the previous and future case law of the CJEU on European data protection standards.

\section{B. A Vision of Checks and Balances}

Accountability, judicial control and judicial review are some of the crucial issues in the 'safe harbour' decision. This is why the decision brings us to the second challenge of both agencies, namely accountability of cross-border cooperation. Today, accountability is the icon for good governance, democratic governance and judicial control. ${ }^{64}$

Judicial control has been considerably strengthened since the pre-Lisbon days of the 'third pillar' framework. ${ }^{65}$ This is a consequence of the improvement and strengthening of judicial control by the CJEU under the Lisbon Treaty. The CJEU may, in principle, exercise a certain level of control, not only over the validity and

59 For a deeper analysis see Sicurella, Scalia (n 27 above) 409 et seq.

60 Case C-362/14 Maximillian Schrems v Data Protection Commissioner, ECLI:EU:C:2015:650.

61 Case C-293/12 Digital Rights Ireland Ltd, ECLI:EU:C:2014:238.

62 Schrems (n 60 above), paras 91 et seq.

63 CJEU, Opinion 1/15 of 26 July 2017, ECLI:EU:C:2017:592.

64 For further details on the concept of accountability S Puntscher Rickmann, 'Security, Freedom and Accountability: Europol and Frontex' in E Guild and F Geyer (eds), Security versus Justice? Police and Judicial Cooperation in the European Union (Ashgate 2009) p 23.

$65 \mathrm{C}$ Ladenburger, 'Police and criminal law in the Treaty of Lisbon: a new dimension for the Community method' (2008) 4 European Criminal Law Review 20, 30; Monaco (n 10 above) 281-82. 
interpretation of the rules laid down in the agencies' constitutive instruments but also over their actions, in accordance with the limits enshrined in the general provisions of the TFEU.

The current Regulation on Europol, as well as the current proposal for a Regulation on Eurojust, address the question of democratic accountability in the broad project of 'Lisbonisation' of both EU agencies. Articles 85 and 88 TFEU explicitly provide for involvement of the European Parliament and national parliaments in democratic oversight of the two bodies, as a result of an overall strengthening of their roles under the Lisbon Treaty. ${ }^{66}$

Regulation (EU) 2016/794 foresees the establishment of a Joint Parliamentary Scrutiny Group (JPSG), which will consist of members of the competent committee of the European Parliament ${ }^{67}$ and the national parliaments. ${ }^{68}$ How the oversight works in practice remains unclear, since this form of accountability is new in the area of European criminal law enforcement. Thus, the JPSG will certainly have a pioneering role. Its task will be to 'politically monitor Europol's activities in fulfilling its mission, including as regards the impact of those activities on the fundamental rights and freedoms of natural persons' (emphasis added). ${ }^{69}$ The reference to 'political monitoring' implies that parliamentary scrutiny is excluded for Europol's day-to-day work, in particular for its operational work. ${ }^{70}$ To take a current topic, the JPSG will therefore not be able to shed light on the issue as to how Europol procures for big data analysis - an issue on which the national governments and the European Commission have not been willing to disclose information. ${ }^{71}$

Europol is obliged to transmit to the JPSG certain documents, such as threat assessments or strategic analysis reports, administrative arrangements, the multiannual programming or annual work programme of Europol, and the evaluation report drawn up by the Commission. Although the JPSG may request other relevant documents, Regulation (EU) 2016/794 clearly intends to deny the parliamentary watchdog access to important information that is marked 'classified. ${ }^{72}$

${ }^{66}$ For Europol see also E Disley/I Barrie/W Hughes/B Patruni, 'Evaluation of the implementation of the Europol Council Decision and of Europol's activities' (Europol, 2012) xxxvii: https://www.europol. europa.eu/sites/default/files/publications/rand_evaluation_report.pdf, accessed 3 August 2017.

67 This is currently the LIBE committee.

68 Regulation (EU) 2016/794 (n 8 above), Art 51.

69 Regulation (EU) 2016/794 (n 8 above), Art 51 para 2, first subparagraph.

70 M Monroy, 'New Europol regulation due to enter into force from May 2017-oversight is likely to remain superficial': http://www.andrej-hunko.de/europa/dokumente/7-beitrag/3190-neweuropol-regulation-due-to-enter-into-force-from-may-2017-oversight-is-likely-to-remain-superficial, accessed 3 August 2017.

${ }^{71}$ Cf Question for written answer of 4 June 2015 by MEP Cornelia Ernst, subject: 'Internet Analysis Coordination Teams at Europol', E-009059-15; Antwort der Bundesregierung auf die Kleine Anfrage der Abgeordneten Andrej Hunko, Jan van Aken, Wolfgang Gehrcke, weiterer Abgeordneter und der Fraktion DIE LINKE._Drucksache 18/4382-Maßnahmen im operativen Europol-Aktionsplan für das Jahr 2015 $z$ u Cyberangriffen mit deutscher Beteiligung, BT-Drucks. 18/4585 of 10 April 2015.

72 Monroy (n 70 above). 
The JPSG should be fed by Europol only with more or less general, even regularly publicly available information, and additional information requests are subject to the requirement of their necessity for the fulfilment of the JPSG's task relating to political monitoring. ${ }^{73}$

Even if the JPSG does indeed identify problems, the JPSG is only entitled to draw up 'summary conclusions' on the political monitoring of Europol and submit those conclusions to the European Parliament and national parliaments. The European Parliament will forward them for information purposes to the Council, the Commission and Europol. ${ }^{74}$ It is to be expected that Europol does not have to fear direct consequences of this parliamentary scrutiny.

Regarding these material, procedural and factual limitations, the- - often long awaited - democratic control of Europol by the parliaments may turn out to be a 'blunt sword' only. ${ }^{75}$

Whether parliamentary oversight of Eurojust will be designed in a parallel way still remains to be seen. ${ }^{76}$ However, the current draft Regulation is less promising. The content of the draft is restricted to setting up limited reporting duties of Eurojust, in particular to transmit its annual activity report to the European Parliament and the national parliaments. Parliamentary discussions on 'specific operational cases' is explicitly excluded. ${ }^{77}$ One might wonder whether it is right that democratic control over Eurojust can remain steps behind the level of control over Europol. However, this issue must be reserved for a more in-depth analysis that cannot be carried out here.

\section{Conclusion}

One thing has become clear in the last decade: both Europol, processing an enormous amount of data and planning to take (police) action in cyberspace, and Eurojust, in charge of facilitating judicial cooperation in the real world in and outside of the European Union, today represent the European face of tackling cross-border crime. Considering the various challenges for criminal justice systems today, the EU Member States and the European agencies must ensure that they can master their tasks. Overall, we believe that-looking at the evolution of Europol and Eurojust - their relationship is not about a 'race', but about joint efforts. Each body has stepped in to fulfill the role and function assigned to them.

73 Cf Regulation (EU) 2016/794 (n 8 above), Art 51 paras 3, 4.

74 Ibid, Art 51 para 5.

75 Critical also is Monroy (n 70 above).

76 See also Weyembergh (n 43 above), (2013) eucrim 129, indicating already a weak transposition of the Lisbon Treaty as regards democratic control on Eurojust.

77 Draft Regulation on Eurojust, Council doc 6643/15, Art 55 para 2. 
Law in action might have turned out differently in certain respects than the drawing board visions of European cooperation in criminal matters.

At a time when Europe is under pressure, its bodies, agencies and institutions serve as an example. When, in certain countries, there is a political shift towards greater nationalism and in others the balance between security and individual freedom shifts more towards security, European bodies, agencies and institutions should stand up for European solutions.

Europol has already been 'Lisbonised', when it started its work as the 'EU Agency for Law Enforcement Cooperation' on 1 May 2017, when the new Regulation replacing and repealing the previous Europol legal framework entered into force. Eurojust still awaits its new 'Lisbonised' legal basis. The delay is also due to the fact that Member States decided to first dedicate themselves to set up the European Public Prosecutor's Office and put aside negotiations on a Regulation on Eurojust. Hence, Europol starts to work according to a mandate that has been endorsed and will intensify its work on operational analysis. A new form of data handling has been established - including data mining operations — which may lead to the not improbable scenario that Europol works as a pace-setter at the European level and Eurojust solely as an insurer of judicial follow-up of police results.

It is therefore all the more important that both EU agencies act jointly as they have done in the past. ${ }^{78}$ At the same time, competent actors at both levels must ensure that European values and the all-embracing commitment to individual rights and liberties are not sacrificed on the altar of short-term law enforcement actions. Standing up for European values concerns Europol, Eurojust, as well as all European institutions and all its citizens.

78 For recent examples, see joint Europol-Eurojust press releases: "'Avalanche" network dismantled in international cyber operation' (1 December 2016); '178 arrests in successful hit against money muling' (22 November 2016); 'EUR 320 million VAT fraud: key targets arrested'(20 October 2016). For the complementarity of Europol and Eurojust see also Weyembergh, Armada and Brière (n 47 above), section 2.1.1.3. 